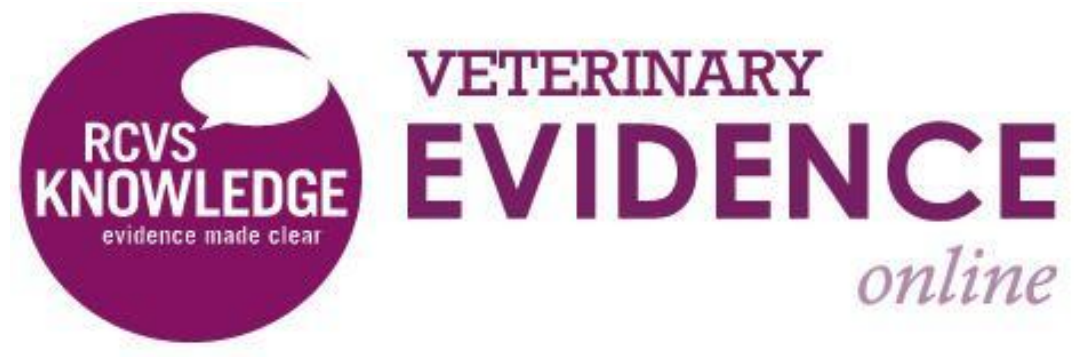

\title{
Are Novel Allergen or Hydrolysed Diets an Effective Means of Reducing the Gastro-intestinal Signs in Dogs With Inflammatory Bowel Disease When Compared to Oral Prednisolone?
}

\section{A Knowledge Summary by}

Adam Swallow BVSc, AFHEA, MRCVs ${ }^{1 *}$

${ }^{1}$ University of Cambridge, The Old Schools, Trinity Ln, Cambridge, CB2 1TN

Corresponding Author (adamswallow26@gmail.com)

ISSN: 2396-9776

Published: 2017

in: Vol 2, Issue 1

DOI: http://dx.doi.org/10.18849/ve.v2i1.56

Reviewed by: Constance White (DVM, PhD) and Nicola

Ackerman (BSc(Hons) RVN CertSAN CertECC 


\section{Clinical bottom line}

Novel allergen or hydrolysed diets are a valid modality for the management of gastro-intestinal symptoms in dogs with chronic enteropathy, however bias in case selection in the literature means a direct comparison of dietary modification versus prednisolone was not able to be achieved. Further prospective trials would be needed to better answer this PICO.

\section{Question}

In (dogs with chronic enteropathy) is the (use of either a novel allergen or a hydrolysed diet) as effective as the (use of prednisolone) in (controlling the gastro-intestinal signs)?

\section{Clinical Scenario}

You have just obtained some histopathology results regarding Eric, a 4 year-old male neutered Staffordshire bull terrier. He has a 4 month history of intermittent, bilious vomiting twice a day and small intestinal diarrhea approximately once every 2-3 days although his stool always seems a bit soft. However, he remains bright and well in himself. He is a healthy weight, and in good body condition score (BCS 5/9). After a course of fenbendazole failed to improve the situation you performed routine haematology, biochemistry and urinalysis (which were unremarkable, including serum TLI, folate and cobalamin) in addition to abdominal ultrasonographic examination. You then elected to proceed to gastroduodenoscopy with mucosal biopsy. The biopsies documented the presence of a mild lymphoplasmacytic enteritis, confirming your suspicions of a chronic enteropathy. Normally, you would lean towards prescribing prednisolone at this time however Eric's owner is not keen on him having steroids unless absolutely necessary, having read about their side effects on the internet. The practice's new graduate recently said something about using hypoallergenic diets for cases like these and you are interested to know if this would be a suitable option for Eric instead of prednisolone.

\section{Summary of the evidence}

IBD: Inflammatory bowel disease

CIBDAI: Canine Inflammatory Bowel Disease Activity Index. Score 0-3= clinically insignificant disease. 4-5= mild IBD. $6-8=$ moderate IBD. $>9=$ severe IBD.

CCECAI = Canine Chronic Enteropathy Clinical Activity Index. Score 0-3= clinically insignificant disease. 4-5= mild IBD. $6-8=$ moderate IBD. 9-11= severe IBD. $>12=$ Very severe IBD.

\begin{tabular}{|r|l|}
\hline \multicolumn{2}{|l|}{ Allenspach (2007) } \\
\hline Population: & $\begin{array}{l}\text { Dogs with signs of chronic enteropathy (vomiting or diarrhea 6+ } \\
\text { weeks). }\end{array}$ \\
\hline Sample size: & 70 dogs $(\mathrm{n}=70)$. \\
\hline Intervention details: & $\begin{array}{l}\text {-Follow up information was available for } 3 \text { years (monthly updates) } \\
\text { with repeat examinations should symptoms worsen. } \\
\text {-All dogs had other causes of their symptoms eliminated and } \\
\text { histological evidence of inflammatory intestinal infiltrates was } \\
\text { documented. } \\
\text {-No dog received antibiotics or corticosteroids or antacids for } 2\end{array}$ \\
\hline
\end{tabular}




\begin{tabular}{|c|c|}
\hline & $\begin{array}{l}\text { weeks prior to entering the trial. } \\
\text {-Prior to referral, dogs received fenbendazole ( } 50 \mathrm{mg} / \mathrm{kg} \text { SID } 5 \text { days) } \\
\text {-All dogs received haematology, biochemistry (inc. TLI, folate and } \\
\text { cobalamin), urinalysis, faecal analysis (smear, culture, zinc flotation), } \\
\text { CRP measurement and abdominal ultrasound. } \\
\text {-All dogs given a CIBDAl score. } \\
\text {-An endoscopy score was given to each dog for the duodenum and } \\
\text { colon ( } 0 \text { being normal- } 3 \text { severe changes to mucosa/ difficulty } \\
\text { insufflating). } \\
-5 \text { biopsy specimens were examined and graded with mild } \\
\text { (infiltrative cells but normal architecture) to severe (infiltrates with } \\
\text { extensive architectural distortion and epithelial immaturity/areas of } \\
\text { epithelial necrosis). } \\
\text {-Dogs given elimination diet for } 10 \text { days; improvement = assigned } \\
\text { "food responsive". No improvement means assigned to "steroid- } \\
\text { treatment group".2mg/kg/d PO for } 210 \text { days, tapered over } 10 \\
\text { weeks. } \\
\text {-Dogs in food responsive group re-evaluated after } 4 \text { weeks with } \\
\text { repeat CIBDAl score and endoscopy/ histopathology scores } \\
\text { assigned. } \\
\text {-The steroid responsive group was re-evaluated in the same way } \\
\text { after } 10 \text { weeks. Steroids had been stopped } 2 \text { weeks prior to this. } \\
\text {-All dogs received elimination diet exclusively for } 14 \text { weeks. } \\
\text {-Dogs not responding to prednisolone underwent a second } 10 \text { week } \\
\text { course. These dogs received ciclosporine } 5 \mathrm{mg} / \mathrm{kg} \text { PO for } 10 \text { weeks } \\
\text { before repeat endoscopy. }\end{array}$ \\
\hline Study design: & - Prospective clinical trial. \\
\hline Outcome studied: & $\begin{array}{l}\text { - To establish predictors of a negative outcome (euthanasia } \\
\text { due to refractory symptoms). }\end{array}$ \\
\hline $\begin{array}{l}\text { Main findings: } \\
\text { (relevant to PICO question): }\end{array}$ & $\begin{array}{l}\text { - } 39 \text { dogs were in the food responsive group. } \\
21 \text { dogs required prednisolone in addition to the elimination } \\
\text { diet. } \\
10 \text { dogs classified as having protein-losing enteropathy (PLE) } \\
\text { as they had panhypoproteinaemia with severe } \\
\text { hypoalbuminaemia (mean albumin } 11.3 \mathrm{~g} / \mathrm{L} \text { SD } 3.19 \text { range } \\
10-18 \mathrm{~g} / \mathrm{L} \text { ref } 24-35 \mathrm{~g} / \mathrm{L} \text { and ascites }+/ \text { - pleural } \\
\text { effusion/peripheral oedema). } \\
\text { - } \text { Variety of breeds represented. } \\
\text { - No statistically significant difference in the sex distribution } \\
\text { between groups. } 34 \text { females overall ( } 22 \text { spayed) and } 36 \\
\text { males ( } 15 \text { neutered). } \\
\text { Mean age } 5.3 y r s \text { (range } 6 \mathrm{~m}-13 y r s \text { ). Mean age of food } \\
\text { responsive group } 3.5 y r s \text { (range } 0.6-7.6 \text { ) which was } \\
\text { significantly less than the steroid responsive group; mean } \\
\text { age } 6.52 y \text { rs, range } 2.1-13 y r s \text {. } \\
\text { - Only } 1 \text { dog died in the food responsive group in a } 3 \text { year } \\
\text { follow up period. } \\
\text { On a provocation diet, } 31 / 39 \text { dogs did not re-develop clinical } \\
\text { signs and remained symptom free. In the other } 8 \text { dogs signs } \\
\text { did recur so food intolerence was suspected. }\end{array}$ \\
\hline
\end{tabular}






\begin{tabular}{|c|c|}
\hline Craven (2004) & \\
\hline Population: & $\begin{array}{l}\text { Dogs with idiopathic inflammatory bowel disease (histologically } \\
\text { confirmed) between } 1995 \text { and } 2002 \text {. }\end{array}$ \\
\hline Sample size: & 80 dogs $(n=80)$. \\
\hline Intervention details: & $\begin{array}{l}\text { - Case records were reviewed and owners contacted by } \\
\text { telephone to complete a questionnaire over the phone. } \\
\text { - Referring vets were also contacted for additional } \\
\text { information if required. } \\
\text { - Dogs were classed as being in either remission (complete } \\
\text { control of signs for } 6 \mathrm{~m}+\text { ), intermittent signs (every } 14 \text { days } \\
\text { or more) or uncontrolled disease (signs seen more } \\
\text { frequently than every } 14 \text { days). } \\
\text { - Owner gave an assessment of quality of life. } \\
\text { - Animals excluded if gastric mucosa inflammation present } \\
\text { alone in presence of helicobacter. }\end{array}$ \\
\hline Study design: & Retrospective observational study. \\
\hline Outcome studied: & Control of clinical signs. \\
\hline
\end{tabular}




\begin{tabular}{|c|c|}
\hline $\begin{array}{l}\text { Main findings: } \\
\text { (relevant to PICO question): }\end{array}$ & 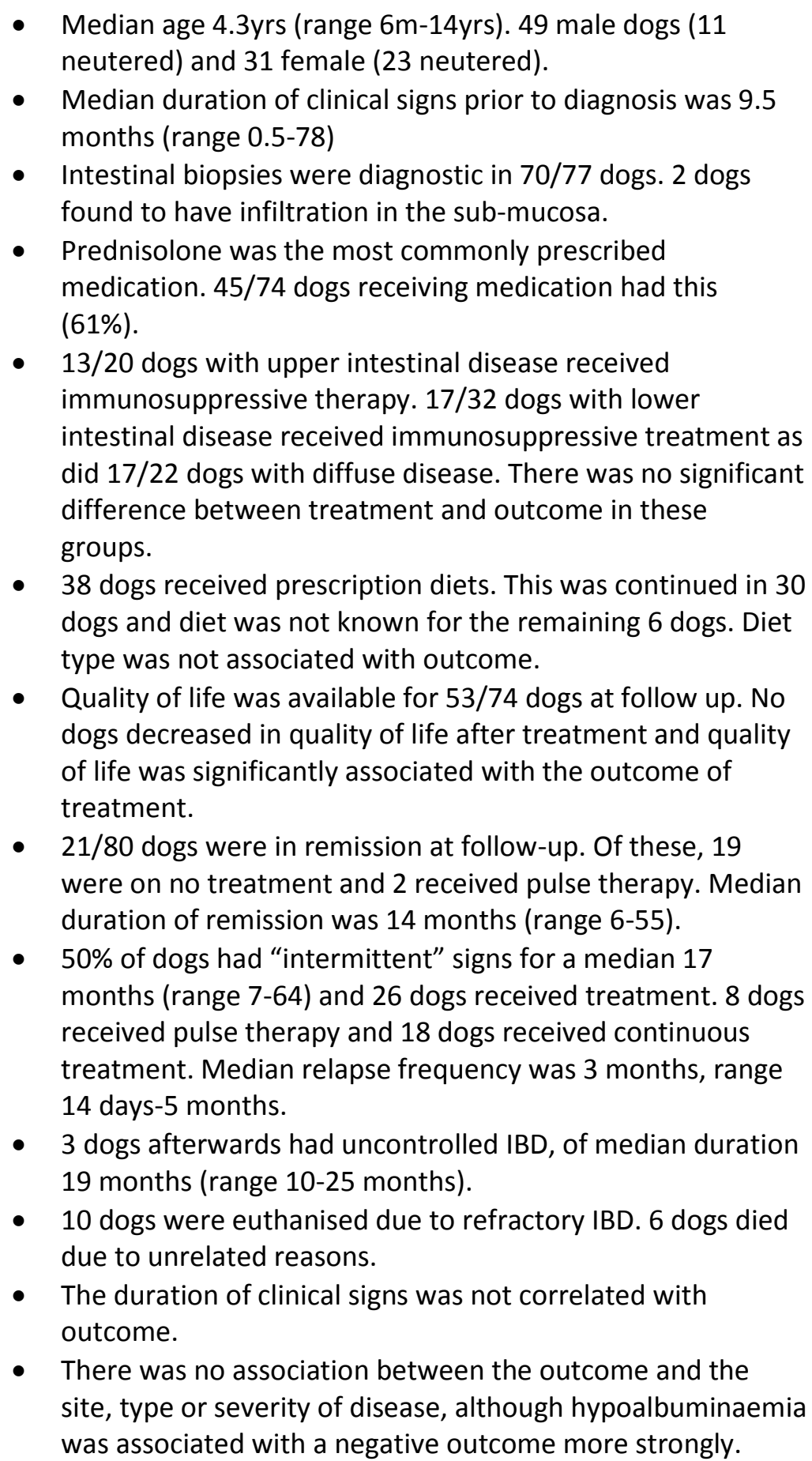 \\
\hline Limitations: & $\begin{array}{l}\text { - Retrospective study has inherent limitations associated with } \\
\text { it, including a higher risk of bias. } \\
\text { - Dogs not re-examined, merely owner responses to } \\
\text { telephone questionnaire. } \\
-\quad \text { No direct comparison between the use of } \\
\text { prednisolone and a hydrolysed diet is possible. } \\
\text { - The authors merely state that a "prescription" diet was } \\
\text { used. The exact details of the diet used are not known. }\end{array}$ \\
\hline
\end{tabular}

Kawano (2016) 


\begin{tabular}{|c|c|}
\hline Population: & $\begin{array}{l}\text { Dogs diagnosed with chronic enteropathy (diagnosed by endoscopic } \\
\text { biopsy), that did not respond to } 2 \text { weeks of antibiotics } \\
\text { (metronidazole, ampicillin or fluoroquinolone) and did not receive } \\
\text { any immunosuppressive agents in the } 2 \text { weeks prior to enrollment. } \\
\text { Endoparasites were ruled out by faecal smear and zinc sulphate } \\
\text { flotation. }\end{array}$ \\
\hline Sample size: & $n=32$ \\
\hline Intervention details: & $\begin{array}{l}\text { - All dogs received the elimination diet for at least } 10 \text { days. } \\
\text { The diet was selected based on the Lymphocyte } \\
\text { Proliferation Test (LPT). If a food resulted in a lymphocyte } \\
\text { proliferation index }>1.2 \% \text { then the allergen was excluded in } \\
\text { the diet trial. } \\
\text { - A positive response to a diet trial (gastro-intestinal } \\
\text { symptoms improved) meant they were classified as "food } \\
\text { responsive" } \\
\text { - If the dog failed to improve on the elimination diet, then } \\
\text { glucocorticoids were prescribed (prednisolone } 0.5- \\
2 \mathrm{mg} / \mathrm{kg} / \text { day). } \\
\text { - Improvements meant they were classified as "steroid } \\
\text { responsive". } \\
\text { - Serum albumin was measured in all cases, }<20 \mathrm{~g} / \mathrm{L} \text { defined } \\
\text { hypoalbuminaemia. }\end{array}$ \\
\hline Study design: & Prospective clinical trial. \\
\hline Outcome studied: & Improvement in the gastro-intestinal symptoms. \\
\hline $\begin{array}{r}\text { Main findings: } \\
\text { (relevant to PICO question): }\end{array}$ & $\begin{array}{l}\text { - Average age of patients: } 5.33 \text { years (range } 4 \text { months-13 } \\
\text { years) } \\
\text { - } 31 / 32 \text { cases displayed a positive LPT to } 2+\text { allergens. } 1 \text { dog } \\
\text { showed } 0 \text { response to LPT. } \\
\text { - After the elimination diet, } 18 / 32 \text { dogs were classified as } \\
\text { food-responsive. } \\
\text { - The remaining } 14 \text { were steroid responsive. } \\
\text { - Successful diets used included Anallergenic ( } n=8 \text { ), Select } \\
\text { Protein (Royal Canin D\&T; } n=1 \text { ), z/d ULTRA allergen-free } \\
\text { ( } n=2 \text { ) and w/d ( } n=1 \text { : Hills), home-made diets ( } n=2 \text { ) and D } \\
\text { Assist KO Select Protein ( } n=1 \text { : Eukanuba). } \\
\text { - Histopathology documented } 25 \text { dogs suffered from } \\
\text { lymphocytic-plasmacytic enteritis ( } 13 \text { dogs were in the } \\
\text { steroid group, other } 12 \text { were food responsive), } 3 \text { dogs had } \\
\text { eosinophilic enteritis and } 4 \text { dogs had "minimal change". } \\
\text { Dogs who were steroid responsive had a higher CCECAI } \\
\text { score than dogs who were food responsive. } 8.6 \text { (mean; SD } \\
\text { 3.3) versus mean } 6.4 \text { (SD } 2.8 \text { ) for food responsive. Overall } \\
\text { mean was } 7.4 ; \text { range } 1-13 \text {. This difference was not } \\
\text { statistically significant. } \\
\text { - } 10 \text { dogs had hypoalbuminaemia. } 8 \text { of these were steroid } \\
\text { responsive and } 2 \text { food responsive. } \\
\text { - Animals with minimal change are advised to undergo dietary } \\
\text { management first. }\end{array}$ \\
\hline
\end{tabular}




\begin{tabular}{|c|c|}
\hline Limitations: & $\begin{array}{l}\text { - No dietary provocation tests performed. } \\
\text { - } \quad \text { receill animals received a hydrolysed diet; some only } \\
\text { The LPT is not a definitive test and the presence of positive } \\
\text { response to food allergens on immunology testing in dogs } \\
\text { with suspected intolerances is controversial. } \\
\text { - It is often recommended to allow } 4 \text { weeks to see an effect } \\
\text { from dietary trials; some dogs were only provided with the } \\
\text { diet for } 10 \text { days. } \\
\text { - Not all dogs will have been through the same protocols so } \\
\text { standardisation is an issue with this study. This may have } \\
\text { introduced a selection bias that favored dogs with milder } \\
\text { disease. } \\
\text { Not a large amount of patients, and there was no long term } \\
\text { follow-up. }\end{array}$ \\
\hline
\end{tabular}

\begin{tabular}{|c|c|}
\hline Mandigers (2010) & \\
\hline Population: & Dogs with chronic enteropathy. \\
\hline Sample size: & 26 dogs $(n=26)$ \\
\hline Intervention details: & $\begin{array}{l}\text { - Dogs were assigned to receive either a hydrolysed diet (18 } \\
\text { dogs) or a highly digestible diet (8 dogs) after diagnosis of a } \\
\text { chronic enteropathy (histologically confirmed). } \\
\text { - } \quad \text { Oogs were re-evaluated } 3 \text { times: at 3, 6-12 and } 36 \text { months. } \\
\text { (complete, partial or none), change in severity of signs } \\
\text { (CIBDAl), change in body weight and need for further } \\
\text { therapy. } \\
\text { - Only dogs with signs of small intestinal disease were } \\
\text { enrolled. } \\
\text { Dogs were excluded if they had received corticosteroids in } \\
\text { the preceding } 3 \text { weeks or if hypoproteinaemia was preset. } \\
\text { Dogs not responding at the time of first follow up then other } \\
\text { treatments added as needed. If a dog had responded then } \\
\text { the dog was challenged with the previous diet for } 7 \text { days to } \\
\text { see if it was an adverse food reaction. } \\
\text { At second follow up, repeat endoscopy was performed if the } \\
\text { owner consented and other therapies offered if they had } \\
\text { relapsed. Other therapies were also available if relapse } \\
\text { occurred at the final re-evaluation. } \\
\text { Complete response: all signs resolved/returned to normal } \\
\text { for the animal. Partial response meant signs were at least } \\
\text { 50\% improved, but not entirely normal. }\end{array}$ \\
\hline Study design: & Randomised, controlled clinical trial (non-blinded). \\
\hline Outcome studied: & $\begin{array}{l}\text { To determine if a hydrolysed diet was superior in managing the } \\
\text { symptoms of chronic enteropathy compared to a highly digestible } \\
\text { diet. }\end{array}$ \\
\hline
\end{tabular}




\begin{tabular}{|c|c|}
\hline $\begin{array}{l}\text { Main findings: } \\
\text { (relevant to PICO question): }\end{array}$ & $\begin{array}{l}\text { Despite randomisation, the CIBDAI was higher in the test } \\
\text { diet group. } \\
\text { Most dogs responded at first evaluation, with no significant } \\
\text { difference between groups. However, significantly more } \\
\text { dogs remained asymptomatic at the } 2 \text { nd and 3rd re- } \\
\text { evaluation, with a significantly greater decrease in CIBDAI. } \\
\text { - There was no significant difference between groups in terms } \\
\text { of duration of clinical signs or patient age/sex/breed/body } \\
\text { weight. } \\
\text { - At first re-evaluation } 16 / 18 \text { dogs had responded to a test } \\
\text { diet. } 12 \text { complete, } 4 \text { partial. } 7 / 8 \text { dogs responded to a control } \\
\text { diet; } 6 \text { fully } 1 \text { partially. ClBDAl decreased significantly in both } \\
\text { groups, but the test diet group decreased significantly more. } \\
\text { Bodyweight increased significantly in the test diet group } \\
\text { (median increase } 4 \% \text {; range } 3-22 \% \text { ) with } 13 \text { dogs increasing, } \\
1 \text { dog decreasing and } 4 \text { dogs being stable. The control group } \\
\text { bodyweight did not change significantly. (median } 0 \% \text {, range - } \\
\text { 9-17\%. } 4 \text { dogs increased, } 2 \text { dogs decreased and } 2 \text { dogs were } \\
\text { stable. Body weight not significantly different between } \\
\text { groups though. } \\
4 \text { of } 6 \text { dogs in the test diet group relapsed on dietary } \\
\text { challenge and } 4 \text { of } 6 \text { of dogs on the control diet relapsed on } \\
\text { challenge. } \\
22 / 23 \text { dogs came for } 2 \text { nd evaluation (other dog died of } \\
\text { unrelated causes). } \\
13 \text { dogs on test diet remained asymptomatic, other } 2 \text { dogs } \\
\text { were partial responders. } 2 \text { of } 7 \text { control dogs remained } \\
\text { asymptomatic, with a higher ClBDAl for this group. } \\
\text { Dogs in control diet group were offered alternative } \\
\text { therapies. } \\
\text { At the final follow up, } 20 / 23 \text { dogs were still on the trial. } 14 \\
\text { were in the test group, } 6 \text { from the control group. } 1 \text { test } \\
\text { group dog experienced occassional symptoms and } 2 \text { did so } \\
\text { after dietary indiscretion. Only } 1 \text { dog in the control group } \\
\text { was still in remission. Other dogs were given alternative } \\
\text { therapy. }\end{array}$ \\
\hline Limitations: & $\begin{array}{l}\text { - Results were based on subjective interpretation of clinical } \\
\text { signs; repeatability of results may be difficult to achieve. } \\
\text { - There was no group receiving prednisolone therapy in this } \\
\text { trial so cannot compare the } 2 \text { modalities of treatment. } \\
\text { - Selection bias is present in that patients with potentially } \\
\text { more severe disease were excluded from the trial. } \\
\text { - There is a potential conflict of interest with the authors } \\
\text { - Many dogs had eosinophilic infiltrates on histopathology, } \\
\text { which is different to the findings outlined in the PICO. }\end{array}$ \\
\hline
\end{tabular}

Marks (2002)

Population: Dogs with confirmed inflammatory bowel disease. All dogs had chronic vomiting and diarrhea of more than 3 months duration. 


\begin{tabular}{|c|c|}
\hline Sample size: & 6 dogs $(n=6)$ \\
\hline Intervention details: & $\begin{array}{l}\text { Dogs were fed Purina HA HypoAllergenic diet; enzymatically } \\
\text { - } \quad \text { Pydrolysed and defatted soy globulin diet. } \\
\text { test that was negative for parasites, physical examination } \\
\text { and endoscopic examination ruling out other gastro- } \\
\text { intestinal pathology and histologically confirmed } \\
\text { inflammation of the stomach or duodenum. } \\
\text { - Owners completed a questionnaire every } 2 \text { weeks for } 10 \\
\text { weeks and repeat endoscopic examination was performed at } \\
\text { the end of } 10 \text { weeks. } \\
\text { - Dogs were recruited over a } 6 \text { month period. } \\
\text { - All dogs were fed twice a day with the test diet according to } \\
\text { their calculated energy requirement (132 } \mathrm{X} \text { BW }{ }^{0.75} \text { ) } \\
\text { Owners assessed faecal consistency daily, with an average } \\
\text { figure collected every } 2 \text { weeks. } \\
\text { "Moderate improvement" represented a } 50 \% \text { improvement } \\
\text { in faecal consistency or a } 50 \% \text { reduction in the frequency of } \\
\text { vomiting. "complete resolution" was also an option. } \\
\text { - Biopsies were examined in a blinded and randomised } \\
\text { fashion by a single pathologist and a semi-quantitative score } \\
\text { was assigned to the samples (0-3 as previously described). }\end{array}$ \\
\hline Study design: & Non-randomised clinical trial. \\
\hline Outcome studied: & $\begin{array}{l}\text { Whether or not dogs improved after a hydrolysed diet and whether } \\
\text { or not there was a histological improvement in the degree of } \\
\text { mucosal inflammation. }\end{array}$ \\
\hline $\begin{array}{l}\text { Main findings: } \\
\text { (relevant to PICO question): }\end{array}$ & $\begin{array}{l}\text { - Mean age was } 3.3 \text { years, range } 1.5-9 \text { years. } \\
\text { - } \text { ranation of vomiting and diarrhea was a mean of } 9 \text { months, } \\
\text { - } 5 \text { dogs had previously failed to respond to a variety of other } \\
\text { medical therapies (excluding corticosteroids) including novel } \\
\text { protein diets. } \\
\text { - Faecal scores improved from a mean of } 91.7 \text { to } 42.5 \text { after } \\
\text { dietary therapy. } \\
4 \text { dogs achieved an "adequate" level of clinical benefit in } \\
\text { terms of faecal consistency and } 2 \text { of these } 4 \text { achieved } \\
\text { complete resolution of the diarrhea within } 3 \text { days. The other } \\
2 \text { dogs experienced a marked improvement over } 12 \text { days. } \\
\text { - For one dog, a complete improvement was not made } \\
\text { despite an improvement in faecal consistency and } \\
\text { intermittent bouts of diarrhea persisted. } \\
2 \text { dogs required additional medical therapy, although } 1 \text { dog } \\
\text { was subsequently diagnosed with inflammatory bowel } \\
\text { disease with concurrent exocrine pancreatic insufficiency. } \\
\text { - Another dog displayed a moderate improvement in the } \\
\text { symptoms, which completely resolved after the addition of } \\
\text { metoclopramide. }\end{array}$ \\
\hline
\end{tabular}




\begin{tabular}{|l|l|}
\hline Limitations: & $\begin{array}{l}\text { - There was no control diet used and no group receiving } \\
\text { prednisolone to allow for direct comparison between the } 2 \\
\text { treatment modalities. }\end{array}$ \\
& $\begin{array}{l}\text { - There was no long term follow-up information available. } \\
\text { - There was no mention of a trial of anti-parasitic medicine to } \\
\text { definitively eliminate endoparasites. }\end{array}$ \\
$\begin{array}{l}\text { - Only } 1 \text { hydrolysed diet was used; sometimes multiple } \\
\text { hypoallergenic diets are required so there is a chance that } \\
\text { the non-responders may have responded to an alternative } \\
\text { diet. }\end{array}$ \\
\begin{tabular}{l} 
Only a small study population was used. \\
\hline
\end{tabular}
\end{tabular}

\section{Appraisal, application and reflection}

The evidence available generally consisted of prospective clinical trials. These generally followed a similar set of inclusion criteria and diagnostic protocol, which allows for greater consistency in the results between papers. However no papers directly compared the use of a hydrolysed diet to the use of prednisolone; prednisolone was often used after dietary manipulation had failed and so it has not been possible to directly compare the 2 treatment modalities. There is a definite paucity in studies looking at long term follow up in dogs after a successful response to a hypoallergenic diet in the short term and so this would be interesting to consider for the future.

Selection bias was probably the most significant issue with the studies appraised above. The inclusion criteria many authors used played a big role in determining which intervention an animal received and the method used meant that only animals who were seemingly more affected progressed onto prednisolone therapy. This is less ideal from an efficacy perspective as it would be ideal to know which intervention yielded a greater response when directly compared. This would also be worthy of consideration for the future.

\section{Methodology Section}

\begin{tabular}{|c|c|}
\hline $\begin{array}{r}\text { Databases searched and dates } \\
\text { covered: }\end{array}$ & Pubmed (1900 - 2017); CAB Abstracts (1983 - 2016) \\
\hline Search terms: & $\begin{array}{l}\text { (Dog OR dogs OR canine) (prednisolone OR diet OR food OR } \\
\text { hydrolysed OR hydrolyzed OR hypoallergenic) (inflammatory bowel } \\
\text { disease OR IBD OR chronic enteropathy OR food responsive } \\
\text { enteropathy) }\end{array}$ \\
\hline Dates searches performed: & $30^{\text {th }}$ August 2016 \\
\hline
\end{tabular}

Exclusion / Inclusion Criteria
\begin{tabular}{|l|l|}
\hline Exclusion: & $\begin{array}{l}\text { Articles that were not relevant to the PICO, articles not available in } \\
\text { the English language and articles where the full text was not } \\
\text { available. Review articles and case reports were also excluded. }\end{array}$ \\
\hline Inclusion: & $\begin{array}{l}\text { Original prospective or retrospective studies relevant to the PICO } \\
\text { where the full text was available to examine. }\end{array}$ \\
\hline
\end{tabular}




\begin{tabular}{|c|c|c|c|c|c|c|}
\hline Database & $\begin{array}{l}\text { Number of } \\
\text { results }\end{array}$ & $\begin{array}{l}\text { Excluded - not } \\
\text { available in the } \\
\text { English language }\end{array}$ & $\begin{array}{l}\text { Excluded - } \\
\text { case reports }\end{array}$ & $\begin{array}{l}\text { Excluded - } \\
\text { review } \\
\text { article }\end{array}$ & $\begin{array}{l}\text { Excluded - not } \\
\text { relevant to the } \\
\text { PICO }\end{array}$ & $\begin{array}{l}\text { Total } \\
\text { relevant } \\
\text { papers }\end{array}$ \\
\hline $\begin{array}{l}\text { NCBI } \\
\text { PubMed }\end{array}$ & 140 & 2 & 4 & 15 & 114 & 5 \\
\hline $\begin{array}{l}\text { CAB } \\
\text { Direct }\end{array}$ & 26 & 0 & 0 & 1 & 25 & 0 \\
\hline
\end{tabular}

\section{CONFLICT OF INTEREST}

The author declares no conflicts of interest.

\section{REFERENCES}

1. Allenspach, K. Wieland, B. Grone, A. (2007) Chronic enteropathies in dogs: evaluation of risk factors for negative outcome. Journal of Veterinary Internal Medicine, 21 (4), pp. 700-8.

DOI: http://dx.doi.org/10.1111/j.1939-1676.2007.tb03011.x

2. Craven, M. et al. (2004) Canine inflammatory bowel disease: retrospective analysis of diagnosis and outcome in 80 cases (1995- 2002). Journal of Small Animal Practice, 45 (7), pp. 336-42.

DOI: http://dx.doi.org/10.1111/i.1748-5827.2004.tb00245.x

3. Kawano, K. et al. (2016) Prevalence of food-responsive enteropathy among dogs with chronic enteropathy in Japan. Journal of Veterinary Medical Science, 78 (8), pp. 1377-1380.

DOI: http://dx.doi.org/10.1292/jvms.15-0457

4. Mandigers, P.J. et al. (2010) A randomized, open-label, positively-controlled field trial of a hydrolyzed protein diet in dogs with chronic small bowel enteropathy. Journal of Veterinary Internal Medicine, 24 (6), pp. 1350-7. DOI: http://dx.doi.org/10.1111/j.1939-1676.2010.0632.x

5. Marks, S.L. Laflamme, D.P. McAlose, D. (2002) Dietary trial using a commercial hypoallegenic diet containing hydrolyzed protein for dogs with inflammatory bowel disease. Veterinary Therapeutics, 3 (2), pp. 109-18. 


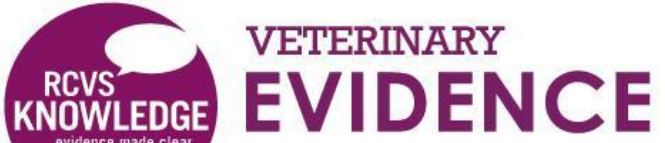 \\ ochese}

\section{Intellectual Property Rights}

Knowledge Summaries are a peer-reviewed article type which aims to answer a clinical question based on the best available current evidence. It does not override the responsibility

of the practitioner. Informed decisions should be made by considering such factors as individual clinical expertise and judgement along with patient's circumstances and owners' values. Knowledge Summaries are a resource to help inform and any opinions expressed within the Knowledge Summaries are the author's own and do not necessarily reflect the view of the RCVS Knowledge.

Authors of Knowledge Summaries submitted to RCVS Knowledge for publication will retain copyright in their work, but will be required to grant to RCVS Knowledge an exclusive license of the rights of copyright in the materials including but not limited to the right to publish, re-

publish, transmit, sell, distribute and otherwise use the materials in all languages and all media throughout the world, and to license or permit others to do so.

Authors will be required to complete a license for publication form, and will in return retain certain rights as detailed on the form.

Veterinary Evidence and EBVM Network are RCVS Knowledge initiatives. For more information please contact us at editor@veterinaryevidence.org

RCVS Knowledge is the independent charity associated with the Royal College of Veterinary Surgeons (RCVS). Our ambition is to become a global intermediary for evidence based veterinary knowledge by providing access to information

that is of immediate value to practicing veterinary professionals and directly contributes to evidence based clinical decision-making.

\section{www.veterinaryevidence.org}

RCVS Knowledge is a registered Charity No. 230886. Registered as a Company limited by guarantee in England and Wales No. 598443.

Registered Office:

Belgravia House

62-64 Horseferry Road

London SW1P 2AF 